\section{Evaluation of Cold Hardiness of Blackberry Seedling Populations}

\author{
Timothy F. Bourne ${ }^{1}$ and J.N. Moore ${ }^{2}$ \\ Department of Horticulture and Forestry, University of Arkansas, \\ Fayetteville, AR 72701
}

Additional index words. fruit breeding, lethal temperatures, Rubus spp.

\begin{abstract}
Twelve seedling blackberry (Rubus spp.) populations were tested over 2 years for cold hardiness of stem and bud tissues. Seedling populations resulted from a partial diallele of crosses made among nine parents representative of three categories of cold hardiness. Viability testing of xylem, phloem, and bud tissues was conducted following exposure to a temperature lethal to $50 \%$ of tested tissue. Significant population effects $(P<0.05)$ occurred for xylem and bud cold hardiness in 1988 and for xylem, phloem, and bud cold hardiness in 1989. Results were similar for the 2 years, although there was a greater discrimination between populations for xylem and phloem cold hardiness in the 2nd year. Seedling populations having 'Darrow' as a parent showed less tissue damage than the other eight populations. The populations having 'Brison' as one parent showed consistently poor hardiness with the exception of one resulting from a cross of 'Brison' $\times$ 'Darrow'. This population showed consistently good hardiness, indicating that dominance effects may play a role in cold hardiness of blackberries.
\end{abstract}

Blackberry production in the United States is limited by low temperatures. Despite widespread interest in blackberry production, relatively few studies have been made on cold hardiness of this crop. Cultivar development requires adequate description of cold hardiness of germplasm, which is not possible without artificial testing, considering the infrequency of test winters. Although cold hardiness for each of several fruit species has been shown to be inherited quantitatively (Aalders and Craig, 1961; Cain and Andersen, 1980; Darrow and Scott, 1947; Mowry, 1964; Watkins and Spangelo, 1970), we found no information on blackberries.

Some information on hardiness of blackberries in Arkansas was gathered following

Received for publication 19 Nov. 1990. Accepted for publication 6 Aug. 1991. Published with the approval of the Director, Arkansas Agricultural Experiment Station. The cost of publishing this paper was defrayed in part by the payment of page charges. Under postal regulations, this paper therefore must be hereby marked advertisement solely to indicate this fact.

'Former graduate assistant. Currently, Research Horticulturist and Breeder, Marko Zaninovich, Inc., Rt. 1 Box 910, Delano, CA 93215.

${ }^{2}$ Distinguished Professor. a test winter in 1969-70, when temperatures fell to $-26 \mathrm{C}$ on 9 Jan. (Moore and Brown, 1971). 'Darrow' and 'Hedrick' blackberries were found to be cold hardy, while 'Lawton' and four cultivars developed in Texas were so severely damaged that no fruit was produced the following season. A later study using viability testing (Warmund et al., 1986) confirmed the hardiness of 'Darrow' buds. Buds of several Arkansas-developed cultivars and lines were found to be less hardy than those of 'Darrow' at five test temperatures. Phloem hardiness of 'Darrow' was less than that of buds at all test temperatures.

Artificial freezing tests of three blackberry cultivars revealed that bud tissues were less hardy than bark tissues (Kraut et al., 1986). Differential thermal analysis of buds indicated that low-temperature exotherms (LTEs) occurred near the lethal temperature for $50 \%$ of tested tissue $\left(\mathrm{LT}_{50}\right)$ of the buds. A later study (Warmund et al., 1988) showed that a variable number of LTEs occurred at various dates. Buds collected in Missouri in November had two LTEs on average, although anatomical studies indicated that as many as nine floral primordia were present. The temperature of the median LTB $(-20.5 \mathrm{C})$ was within $0.5 \mathrm{C}$ of the $\mathrm{LT}_{50}$ value $(-20 \mathrm{C}) \mathrm{de}-$ rived from viability testing. January sampling in Arkansas revealed a median LTB of $-28 \mathrm{C}$, which was equal to the $\mathrm{LT}_{50}$ calculated from viability testing. However, as many as six LTEs per bud were recorded at this date. Buds collected in March in Arkansas averaged five LTEs, but the median LTE $(-22 \mathrm{C})$ was $4 \mathrm{C}$ hardier than the calculated $\mathrm{LT}_{50}(-18 \mathrm{C})$. Samples taken the following September in-Arkansas revealed one or no LTE with poor agreement between the median LTE value $(-16.5 \mathrm{C})$ and the $\mathrm{LT}_{50}$ value $(-12 \mathrm{C})$. It appears that while LTEs are valuable for determining midwinter hardiness, the effectiveness of their use is limited in fall and spring.

The objective of this experiment was to evaluate cold hardiness of seedling populations of complex hybrids of tetraploid blackberries.

About 2000 blackberry seedlings derived from 12 crosses among nine parents made in 1986 were planted in the field in a randomized complete-block design at Clarksville, Ark., in Spring 1987 (Table 1). Relative hardiness of parental genotypes was determined over several years of field trials, although no previous cold hardiness research in blackberries had been conducted (Moore and Brown, 1971). Plants were grown for one season, and canes were sampled during the next two winters. At each sampling date, a single two-node stem section was collected from each plant. The middle portions of stems were sampled to avoid late-season growth near the apex. Samples were placed in plastic bags and transferred to an insulated cooler containing ice. No attempt was made to relate samples to their individual source plants. Samples were stored at the laboratory at $0 \pm 2 \mathrm{C}$ until tested.

Sample preparation consisted of wrapping stem sections from each progeny-replication combination in paper towels moistened with tap water. Stem sections and paper were then wrapped with aluminum foil. Copper-constantan thermocouples were placed in six of the sample bundles to monitor bundle temperature. Two replications were frozen at a time, since space limitations did not allow freezing of all samples together. The chamber (Tenney Jr., Tenney Inc., Union, N.J.) was kept at 0C for $30 \mathrm{~min}$, followed by a temperature drop of $3 \mathrm{C} / \mathrm{h}$ to the estimated $\mathrm{LT}_{50}$ of the samples (Warmund et al., 1986). The temperatures used at each sampling time 
Table 1. Blackberry seedling population parentage and population sizes.

\begin{tabular}{|c|c|c|c|c|}
\hline \multirow[b]{2}{*}{ Population } & \multirow[b]{2}{*}{ Parentage } & \multirow{2}{*}{$\begin{array}{l}\text { Parental } \\
\text { cold } \\
\text { hardiness }\end{array}$} & \multicolumn{2}{|c|}{$\begin{array}{c}\text { Seedlings } \\
\text { in population (no.) }\end{array}$} \\
\hline & & & Year 1 & Year 2 \\
\hline 8643 & Brison $\times$ Rosborough & $S \times S$ & 162 & 95 \\
\hline 8644 & Brison $\times$ Brazos & $S \times S$ & 158 & 93 \\
\hline 8645 & Brison x A-937 & $S \times I$ & 166 & 96 \\
\hline 8646 & Brison x A-967 & $S \times I$ & 74 & 65 \\
\hline 8647 & Brison $\times$ Darrow & $\mathrm{S} \times \mathrm{H}$ & 71 & 72 \\
\hline 8648 & Brison $\times$ Lowden & $\mathrm{S} \times \mathrm{H}$ & 167 & 95 \\
\hline 8649 & A-937 x A-967 & I X I & 28 & 27 \\
\hline 8650 & A-937 x A-1058 & $I \times I$ & 170 & 98 \\
\hline 8651 & A-937 x Darrow & $\mathrm{I} \times \mathrm{H}$ & 67 & 58 \\
\hline 8652 & A-937 x Lowden & $\mathrm{I} \times \mathrm{H}$ & 170 & 94 \\
\hline 8653 & Darrow $\times$ Lowden & $\mathrm{H} \times \mathrm{H}$ & 163 & 100 \\
\hline 8654 & Darrow $\times$ Eldorado & $\mathrm{H} \times \mathrm{H}$ & 152 & 97 \\
\hline
\end{tabular}

${ }^{7}$ Denotes relative hardiness: $\mathrm{S}=$ susceptible; $\mathrm{I}=$ intermediate; $\mathrm{H}=$ hardy.

Table 2. Mean separation of blackberry seedling population data: average percentage undamaged xylem. phloem. and bud tissues. 2 and 28 Feb. 1988. combined.

\begin{tabular}{llll}
\hline \hline Population & Xylem & Phloem & Bud \\
\hline 8651 & $72.9 \mathrm{~A}^{\mathrm{z}}$ & $52.9 \mathrm{~A}$ & $51.7 \mathrm{BC}$ \\
8653 & $72.2 \mathrm{AB}$ & $49.5 \mathrm{~A}$ & $67.4 \mathrm{AB}$ \\
8654 & $63.1 \mathrm{AB}$ & $54.5 \mathrm{~A}$ & $76.3 \mathrm{~A}$ \\
8647 & $60.1 \mathrm{ABC}$ & $53.1 \mathrm{~A}$ & $59.1 \mathrm{AB}$ \\
8648 & $60.0 \mathrm{ABC}$ & $58.4 \mathrm{~A}$ & $32.8 \mathrm{CDE}$ \\
8650 & $58.4 \mathrm{ABC}$ & $51.6 \mathrm{~A}$ & $25.8 \mathrm{DE}$ \\
8652 & $57.6 \mathrm{ABC}$ & $47.9 \mathrm{~A}$ & $48.7 \mathrm{BC}$ \\
8649 & $55.9 \mathrm{BC}$ & $51.4 \mathrm{~A}$ & $22.4 \mathrm{E}$ \\
8646 & $48.8 \mathrm{BC}$ & $48.8 \mathrm{~A}$ & $47.5 \mathrm{BCD}$ \\
8645 & $48.1 \mathrm{BC}$ & $44.6 \mathrm{~A}$ & $32.8 \mathrm{CDE}$ \\
8643 & $46.8 \mathrm{C}$ & $43.2 \mathrm{~A}$ & $19.4 \mathrm{E}$ \\
8644 & $44.8 \mathrm{C}$ & $38.8 \mathrm{~A}$ & $25.7 \mathrm{DE}$ \\
\hline
\end{tabular}

${ }^{7}$ Numbers followed by the same letter are not different at $\mathrm{P}=0.05$.

Table 3.Mean separation of blackberry seedling population data: average percentage undamaged xylem, phloem, and bud tissues, 13 Jan. 1989.

\begin{tabular}{lccc}
\hline \hline Population & Xylem & Phloem & Bud \\
\hline 8654 & $59.1 \mathrm{~A}^{\mathbf{x}}$ & $17.4 \mathrm{~A}$ & $58.3 \mathrm{~A}$ \\
8647 & $57.8 \mathrm{~A}$ & $7.1 \mathrm{BC}$ & $55.3 \mathrm{~A}$ \\
8653 & $54.0 \mathrm{AB}$ & $15.8 \mathrm{AB}$ & $72.8 \mathrm{~A}$ \\
8649 & $48.4 \mathrm{AB}$ & $0.0 \mathrm{C}$ & $28.8 \mathrm{BC}$ \\
8651 & $4.5 \mathrm{C}$ & $68.3 \mathrm{~A}$ \\
8648 & $43.7 \mathrm{ABC}$ & $3.6 \mathrm{C}$ & $27.1 \mathrm{BC}$ \\
8652 & $32.9 \mathrm{BCD}$ & $1.1 \mathrm{C}$ & $29.8 \mathrm{~B}$ \\
8650 & $21.0 \mathrm{CDE}$ & $3.5 \mathrm{C}$ & $14.2 \mathrm{BCD}$ \\
8646 & $19.4 \mathrm{DE}$ & $3.8 \mathrm{C}$ & $8.3 \mathrm{CD}$ \\
8645 & $12.5 \mathrm{DE}$ & $2.0 \mathrm{C}$ & $16.6 \mathrm{BCD}$ \\
8643 & $12.1 \mathrm{DE}$ & $0.0 \mathrm{C}$ & $5.0 \mathrm{D}$ \\
8644 & $10.2 \mathrm{DE}$ & $1.3 \mathrm{C}$ & $7.8 \mathrm{CD}$ \\
\hline
\end{tabular}

${ }^{2}$ Numbers followed by the same letter are not different at $\mathrm{P}=0.05$.

were: 2 Feb. 1988. -25C: 28 Feb. 1988. $-10 \mathrm{C}$; 13 Jan. 1989, -20C.

Samples were kept at these temperatures for $30 \mathrm{~min}$ and were removed, placed in plastic bags, and kept on ice for 1 week. One day before evaluation, samples were placed at room temperature to enhance browning of damaged tissues. Samples were dissected longitudinally with a razor blade and examined under a dissecting microscope at $\times 30$ magnification. Tissues were rated as either damaged or undamaged. Tissues rated as undamaged were bright green with no evidence of browning. Tissues that had any browning were rated as damaged. Average survival response was calculated for each replication. Analysis of variance was performed on average population response.

Some seedling plants died naturally between the first and 2nd years of data collec- tion (Table 1). A miscount apparently was responsible for the larger sample size in population 8647 in the 2nd year. Although Winter 1987-88 did have some extremely low temperatures, death due to low temperatures was not confirmed. Most of the larger populations lost many plants. No clear survival advantage of one population over others was seen in the larger population (> 100 plants).

Analyses of variance were performed on data collected for damage to xylem, phloem, and buds in 1988 (data not shown). Significant effects due to population and date were present in xylem and phloem tissue damage, but only population effects were seen in buds. Three populations were superior for xylem, phloem, and buds: 8647 (susceptible $\mathrm{x}$ hardy), 8653 (hardy x hardy), and 8654 (H x H) (Table 2). Populations with a single hardy parent showed no more xylem tissue damage than did populations resulting from crosses of two hardy parents. Six of the seven populations with the hardiest xylem had at least one hardy parent, with only 8650 resulting from a cross of two parents intermediate in hardiness.

Of the three variables measured, bud survival showed the most classes in the mean separation. Three of the four crosses in which 'Darrow' was a parent $(8647,8651,8653$, 8654 ) were in the highest survival category. Of the six populations with the lowest survival, only one involved a parent classified as hardy.

Analyses of variance were performed on the 1989 data as in 1988 (data not shown). Significant effects due to populations were present for all three characteristics (Table 3). Only five populations were found in the hardiest class of xylem survival. All four crosses involving 'Darrow' plus one of the intermediate $\mathrm{x}$ intermediate populations (8649) were in this class. Six populations were in the least hardy class. Only one of these (8652) involved a parent rated as hardy.

Phloem was damaged more severely than the other tissues examined in 1989. Populations showing the least phloem damage were derived from crosses involving 'Darrow'. Ten of the 12 crosses fell in the category with the least undamaged tissue.

Tissue damage estimates for xylem, phloem, and buds across the 2 years clearly indicate the superiority of 'Darrow' in conferring hardiness to its progeny. The data for 1988 do not show this as clearly as those for 1989. In general, undamaged tissue means were high enough in the first year that the means separation was not very decisive, which was particularly true for xylem and phloem tissues. We attribute this result to our failure to freeze the tissue at a low enough temperature at both dates in 1988. In the case of bud tissues, the populations with 'Darrow' parentage showed the least damage.

Data from 1989 showed greater damage of all tissues than in 1988. For each variable, the 'Darrow' progeny had the highest average undamaged tissue, although this was most clear in the case of bud tissues. 'Darrow' progeny had significantly more undamaged bud tissue than all other populations.

With the exception of populations 8647 ('Brison' $x$ 'Darrow') and 8648 ('Brison $x$ 'Lowden'), progeny populations resulting from 'Brison', a cold-susceptible cultivar, had the least undamaged tissue of all crosses. Poor survival in 'Brison' populations was more clear in the 2nd year, when damage was greater overall.

Populations 8649 and 8650, resulting from crosses of parents of intermediate hardiness, were generally intermediate in response. The data for 1988 indicate this most clearly for bud tissue damage. In 1989, phloem and bud tissues indicated an intermediate to high level of tissue damage for these populations.

We conclude that cold hardiness of blackberries is a quantitatively inherited characteristic. This contention is supported by the fact that tissue damage of. populations of progeny could have been predicted from parental re- 
sponse: in general, tender parents produced tender progeny, intermediate parents produced intermediate progeny, and hardy parents produced hardy progeny. The fact that population 8647 had a consistently high survival, in spite of having the tender parent 'Brison', indicates that dominance may play a role in determining cold hardiness response in blackberries.

\section{Literature Cited}

Aalders, L.E. and D.L. Craig. 1961. Progeny performance of seven red raspberry varieties in Nova Scotia. Can. J. Plant Sci. 41:466-468.
Cain, D.W. and R.L. Andersen. 1980. Inheritance of wood hardiness among hybrids of commercial and wild Asian peach genotypes. J. Amer. Soc. Hort. Sci. 105:349-354.

Darrow, G.M. and D.H. Scott. 1947. Breeding for cold hardiness of strawberry flowers. Proc. Amer. Soc. Hort. Sci. 50:239-242.

Kraut, J.L., C.S. Walsh, and E.N. Ashworth. 1986. Acclimation and winterhardiness patterns in the eastern thornless blackberry. J. Amer. Soc. Hort. Sci. 111:347-352.

Moore, J.N. and G.R. Brown. 1971. Susceptibility of blackberry and blueberry cultivars to winter injury. Fruit Var. Hort. Dig. 25:31-32.
Mowry, J.B. 1964. Inheritance of cold hardiness of dormant Peach flower buds. Proc. Amer. Soc. Hort. Sci. 85:128-133.

Wannund, M.R., M.F. George, and J.R. Clark. 1986. Bud mortality and phloem injury of six blackberry cultivars subjected to low temperatures. Fruit Var. J. 40:144-146.

Warmund, M.R.,, M.F. George, and B.G. Cumbie. 1988. Supercooling in 'Darrow' blackberry buds. J. Amer. Soc. Hort. Sci. 113:418-422.

Watkins, R. and L.P.S. Spangelo. 1970. Components of genetic variance for plant survival and vigor of apple trees. Theoretical and Applied Genet. 40:195-203. 
Table 1. Blackberry seedling population parentage and population sizes.

\begin{tabular}{|c|c|c|c|c|}
\hline \multirow[b]{2}{*}{ Population } & \multirow[b]{2}{*}{ Parentage } & \multirow{2}{*}{$\begin{array}{l}\text { Parental } \\
\text { cold } \\
\text { hardiness }\end{array}$} & \multicolumn{2}{|c|}{$\begin{array}{c}\text { Seedlings } \\
\text { in population (no.) }\end{array}$} \\
\hline & & & Year 1 & Year 2 \\
\hline 8643 & Brison $\times$ Rosborough & $S \times S$ & 162 & 95 \\
\hline 8644 & Brison $\times$ Brazos & $S \times S$ & 158 & 93 \\
\hline 8645 & Brison x A-937 & $S \times I$ & 166 & 96 \\
\hline 8646 & Brison x A-967 & $S \times I$ & 74 & 65 \\
\hline 8647 & Brison $\times$ Darrow & $\mathrm{S} \times \mathrm{H}$ & 71 & 72 \\
\hline 8648 & Brison $\times$ Lowden & $\mathrm{S} \times \mathrm{H}$ & 167 & 95 \\
\hline 8649 & A-937 x A-967 & I X I & 28 & 27 \\
\hline 8650 & A-937 x A-1058 & $I \times I$ & 170 & 98 \\
\hline 8651 & A-937 x Darrow & $\mathrm{I} \times \mathrm{H}$ & 67 & 58 \\
\hline 8652 & A-937 x Lowden & $\mathrm{I} \times \mathrm{H}$ & 170 & 94 \\
\hline 8653 & Darrow $\times$ Lowden & $\mathrm{H} \times \mathrm{H}$ & 163 & 100 \\
\hline 8654 & Darrow $\times$ Eldorado & $\mathrm{H} \times \mathrm{H}$ & 152 & 97 \\
\hline
\end{tabular}

${ }^{7}$ Denotes relative hardiness: $\mathrm{S}=$ susceptible; $\mathrm{I}=$ intermediate; $\mathrm{H}=$ hardy.

Table 2. Mean separation of blackberry seedling population data: average percentage undamaged xylem. phloem. and bud tissues. 2 and 28 Feb. 1988. combined.

\begin{tabular}{llll}
\hline \hline Population & Xylem & Phloem & Bud \\
\hline 8651 & $72.9 \mathrm{~A}^{\mathrm{z}}$ & $52.9 \mathrm{~A}$ & $51.7 \mathrm{BC}$ \\
8653 & $72.2 \mathrm{AB}$ & $49.5 \mathrm{~A}$ & $67.4 \mathrm{AB}$ \\
8654 & $63.1 \mathrm{AB}$ & $54.5 \mathrm{~A}$ & $76.3 \mathrm{~A}$ \\
8647 & $60.1 \mathrm{ABC}$ & $53.1 \mathrm{~A}$ & $59.1 \mathrm{AB}$ \\
8648 & $60.0 \mathrm{ABC}$ & $58.4 \mathrm{~A}$ & $32.8 \mathrm{CDE}$ \\
8650 & $58.4 \mathrm{ABC}$ & $51.6 \mathrm{~A}$ & $25.8 \mathrm{DE}$ \\
8652 & $57.6 \mathrm{ABC}$ & $47.9 \mathrm{~A}$ & $48.7 \mathrm{BC}$ \\
8649 & $55.9 \mathrm{BC}$ & $51.4 \mathrm{~A}$ & $22.4 \mathrm{E}$ \\
8646 & $48.8 \mathrm{BC}$ & $48.8 \mathrm{~A}$ & $47.5 \mathrm{BCD}$ \\
8645 & $48.1 \mathrm{BC}$ & $44.6 \mathrm{~A}$ & $32.8 \mathrm{CDE}$ \\
8643 & $46.8 \mathrm{C}$ & $43.2 \mathrm{~A}$ & $19.4 \mathrm{E}$ \\
8644 & $44.8 \mathrm{C}$ & $38.8 \mathrm{~A}$ & $25.7 \mathrm{DE}$ \\
\hline
\end{tabular}

${ }^{7}$ Numbers followed by the same letter are not different at $\mathrm{P}=0.05$.

Table 3.Mean separation of blackberry seedling population data: average percentage undamaged xylem, phloem, and bud tissues, 13 Jan. 1989.

\begin{tabular}{lccc}
\hline \hline Population & Xylem & Phloem & Bud \\
\hline 8654 & $59.1 \mathrm{~A}^{\mathbf{x}}$ & $17.4 \mathrm{~A}$ & $58.3 \mathrm{~A}$ \\
8647 & $57.8 \mathrm{~A}$ & $7.1 \mathrm{BC}$ & $55.3 \mathrm{~A}$ \\
8653 & $54.0 \mathrm{AB}$ & $15.8 \mathrm{AB}$ & $72.8 \mathrm{~A}$ \\
8649 & $48.4 \mathrm{AB}$ & $0.0 \mathrm{C}$ & $28.8 \mathrm{BC}$ \\
8651 & $4.5 \mathrm{C}$ & $68.3 \mathrm{~A}$ \\
8648 & $43.7 \mathrm{ABC}$ & $3.6 \mathrm{C}$ & $27.1 \mathrm{BC}$ \\
8652 & $32.9 \mathrm{BCD}$ & $1.1 \mathrm{C}$ & $29.8 \mathrm{~B}$ \\
8650 & $21.0 \mathrm{CDE}$ & $3.5 \mathrm{C}$ & $14.2 \mathrm{BCD}$ \\
8646 & $19.4 \mathrm{DE}$ & $3.8 \mathrm{C}$ & $8.3 \mathrm{CD}$ \\
8645 & $12.5 \mathrm{DE}$ & $2.0 \mathrm{C}$ & $16.6 \mathrm{BCD}$ \\
8643 & $12.1 \mathrm{DE}$ & $0.0 \mathrm{C}$ & $5.0 \mathrm{D}$ \\
8644 & $10.2 \mathrm{DE}$ & $1.3 \mathrm{C}$ & $7.8 \mathrm{CD}$ \\
\hline
\end{tabular}

${ }^{2}$ Numbers followed by the same letter are not different at $\mathrm{P}=0.05$.

were: 2 Feb. 1988. -25C: 28 Feb. 1988. $-10 \mathrm{C}$; 13 Jan. 1989, -20C.

Samples were kept at these temperatures for $30 \mathrm{~min}$ and were removed, placed in plastic bags, and kept on ice for 1 week. One day before evaluation, samples were placed at room temperature to enhance browning of damaged tissues. Samples were dissected longitudinally with a razor blade and examined under a dissecting microscope at $\times 30$ magnification. Tissues were rated as either damaged or undamaged. Tissues rated as undamaged were bright green with no evidence of browning. Tissues that had any browning were rated as damaged. Average survival response was calculated for each replication. Analysis of variance was performed on average population response.

Some seedling plants died naturally between the first and 2nd years of data collec- tion (Table 1). A miscount apparently was responsible for the larger sample size in population 8647 in the 2nd year. Although Winter 1987-88 did have some extremely low temperatures, death due to low temperatures was not confirmed. Most of the larger populations lost many plants. No clear survival advantage of one population over others was seen in the larger population (> 100 plants).

Analyses of variance were performed on data collected for damage to xylem, phloem, and buds in 1988 (data not shown). Significant effects due to population and date were present in xylem and phloem tissue damage, but only population effects were seen in buds. Three populations were superior for xylem, phloem, and buds: 8647 (susceptible $\mathrm{x}$ hardy), 8653 (hardy x hardy), and 8654 (H x H) (Table 2). Populations with a single hardy parent showed no more xylem tissue damage than did populations resulting from crosses of two hardy parents. Six of the seven populations with the hardiest xylem had at least one hardy parent, with only 8650 resulting from a cross of two parents intermediate in hardiness.

Of the three variables measured, bud survival showed the most classes in the mean separation. Three of the four crosses in which 'Darrow' was a parent $(8647,8651,8653$, 8654 ) were in the highest survival category. Of the six populations with the lowest survival, only one involved a parent classified as hardy.

Analyses of variance were performed on the 1989 data as in 1988 (data not shown). Significant effects due to populations were present for all three characteristics (Table 3). Only five populations were found in the hardiest class of xylem survival. All four crosses involving 'Darrow' plus one of the intermediate $\mathrm{x}$ intermediate populations (8649) were in this class. Six populations were in the least hardy class. Only one of these (8652) involved a parent rated as hardy.

Phloem was damaged more severely than the other tissues examined in 1989. Populations showing the least phloem damage were derived from crosses involving 'Darrow'. Ten of the 12 crosses fell in the category with the least undamaged tissue.

Tissue damage estimates for xylem, phloem, and buds across the 2 years clearly indicate the superiority of 'Darrow' in conferring hardiness to its progeny. The data for 1988 do not show this as clearly as those for 1989. In general, undamaged tissue means were high enough in the first year that the means separation was not very decisive, which was particularly true for xylem and phloem tissues. We attribute this result to our failure to freeze the tissue at a low enough temperature at both dates in 1988. In the case of bud tissues, the populations with 'Darrow' parentage showed the least damage.

Data from 1989 showed greater damage of all tissues than in 1988. For each variable, the 'Darrow' progeny had the highest average undamaged tissue, although this was most clear in the case of bud tissues. 'Darrow' progeny had significantly more undamaged bud tissue than all other populations.

With the exception of populations 8647 ('Brison' $x$ 'Darrow') and 8648 ('Brison $x$ 'Lowden'), progeny populations resulting from 'Brison', a cold-susceptible cultivar, had the least undamaged tissue of all crosses. Poor survival in 'Brison' populations was more clear in the 2nd year, when damage was greater overall.

Populations 8649 and 8650, resulting from crosses of parents of intermediate hardiness, were generally intermediate in response. The data for 1988 indicate this most clearly for bud tissue damage. In 1989, phloem and bud tissues indicated an intermediate to high level of tissue damage for these populations.

We conclude that cold hardiness of blackberries is a quantitatively inherited characteristic. This contention is supported by the fact that tissue damage of. populations of progeny could have been predicted from parental re- 
sponse: in general, tender parents produced tender progeny, intermediate parents produced intermediate progeny, and hardy parents produced hardy progeny. The fact that population 8647 had a consistently high survival, in spite of having the tender parent 'Brison', indicates that dominance may play a role in determining cold hardiness response in blackberries.

\section{Literature Cited}

Aalders, L.E. and D.L. Craig. 1961. Progeny performance of seven red raspberry varieties in Nova Scotia. Can. J. Plant Sci. 41:466-468.
Cain, D.W. and R.L. Andersen. 1980. Inheritance of wood hardiness among hybrids of commercial and wild Asian peach genotypes. J. Amer. Soc. Hort. Sci. 105:349-354.

Darrow, G.M. and D.H. Scott. 1947. Breeding for cold hardiness of strawberry flowers. Proc. Amer. Soc. Hort. Sci. 50:239-242.

Kraut, J.L., C.S. Walsh, and E.N. Ashworth. 1986. Acclimation and winterhardiness patterns in the eastern thornless blackberry. J. Amer. Soc. Hort. Sci. 111:347-352.

Moore, J.N. and G.R. Brown. 1971. Susceptibility of blackberry and blueberry cultivars to winter injury. Fruit Var. Hort. Dig. 25:31-32.
Mowry, J.B. 1964. Inheritance of cold hardiness of dormant Peach flower buds. Proc. Amer. Soc. Hort. Sci. 85:128-133.

Wannund, M.R., M.F. George, and J.R. Clark. 1986. Bud mortality and phloem injury of six blackberry cultivars subjected to low temperatures. Fruit Var. J. 40:144-146.

Warmund, M.R.,, M.F. George, and B.G. Cumbie. 1988. Supercooling in 'Darrow' blackberry buds. J. Amer. Soc. Hort. Sci. 113:418-422.

Watkins, R. and L.P.S. Spangelo. 1970. Components of genetic variance for plant survival and vigor of apple trees. Theoretical and Applied Genet. 40:195-203. 